\title{
Female patrons of early buddhism in ancient india: an epigraphical analysis
}

\begin{abstract}
According to the 2001 census, India, the land of the Buddha is home to $3,881,052$ female Buddhist devotees. ${ }^{1}$ There are an estimated 300 million Buddhist women worldwide, including more than 130,000 nuns. This growing community stands proudly on the shoulders of the lay women devotees and nuns who have been an integral part of the Sangha, almost since its inception. However, apart from the heartrendering stories narrated in the Therigatha, ${ }^{1}$ in which the early bhikkhuni recount their struggles and accomplishments along the road to arahatship, no historical evidence has yet been given due significance. As a result, the record of early Buddhist women's contributions rests entirely with the literary characters of the Therigatha.
\end{abstract}

Volume I Issue 4 - 2017

Rupali Mokashi

Associate Professor, Department of History, University of Mumbai, India

Correspondence: Rupali Mokashi,Associate Professor, Department of History, University of Mumbai, India; Email dr.rupalimokashi@gmail.com

Received: May 18, 2017 | Published: July 03, 2017

Keywords: alzheimer's disease, cognitive functions, lexical-semantic level

\section{Introduction}

The role of ancient Indian Buddhist women in espousing its eternal traditions is mostly determined by analyzing the famous female protagonists depicted in literary works or the norms laid down in scripture, thus neglecting "real" women. Their patronage and contributions towards the propagation of Buddhism were rarely brought to light. This is a major lacuna in Buddhist history.

It was in Mauryan period that Buddhism emerged as a distinct religion with great potential for expansion. Emperor Ashoka ${ }^{1}$ initiated the tradition of engraving inscriptions in India, which became widely popular thereafter. A large number of Buddhist donors' inscriptions help to reconstruct a more precise framework for understanding the followers of Dhamma, especially women. A close survey of these inscriptions discovered from Deccan ${ }^{2}$ during the early centuries of Christian Era bring to light the contributions of more than 300 women who embraced Dhamma either as laywomen or nuns. Though the contributions of all of them are noteworthy, due to the page restraint, this paper will highlight few eminent women belonging to different social stratas of ancient Indian society during early centuries of the Christian era who espoused the cause of propagation of Buddhism.

The Allahabad pillar inscription mentions Karuvaki, ${ }^{2,3}$ the second chief queen of emperor Ashoka. She is the first Buddhist woman to figure by name in Indian inscriptions incised on the famous Ashokan pillar at Allahabad otherwise known, as the 'Queen's pillar edict'. The record in form as well as content is a command from the king to his Mahamantras, ${ }^{3}$ who were in turn asked to take a note of the queen's donations.

Various architectural styles emerged with the spread of Buddhism as well as growth of brisk trade with the western world Deccan after 2nd Century BCE, such as the Stupa, Chaitya and Vihara in the Sahyadri mountain ranges at Karle, Bhaje, Nasik, Junnar to name a

${ }^{1}$ Ashoka was an Indian emperor of the Maurya Dynasty who ruled over vast areas of the Indian subcontinent from $269 \mathrm{BCE}$ to $232 \mathrm{BCE}$

${ }^{2}$ Geographically it covers a large plateau bounded on both the sides by Arabian Sea and the Bay of Bengal below river Narmada. This area was known as Dakshinapatha in Sanskrit

${ }^{3}$ Ministers few. The need for a place of worship and the residential requirements of the monks and the nuns led to their speedy growth. Inscriptions tell us that these architectural attainments partially owed their existence to endowments made by women who belonged to different social groups. It can be observed that queens, laywomen, nuns and even courtesans contributed according to their individual financial capacities.

The magnificent stupa of Sanchi partially owed its existence to eighty-seven female devotees of which only 'Vakalaye Devi' appears to be a royal woman and remaining were 36 nuns 50 laywomen. Sondegva, wife of Siharakhita, ${ }^{4}$ Naga the wife of Kamdadi gamiya sethin (trader of town Kandadi), Gharini ${ }^{4}$ Sijha from Virohakata, ${ }^{5}$ Sangharakshita the antevasini ${ }^{5}$ (female pupil) of Yasila, ${ }^{6}$ Bhicchuni Kadi from Ujjaini ${ }^{7}$ are names of some laywomen as well as nuns whose donations have been recorded at Sanchi. In fact, the total numbers of female benefactors analyzed here of royal descent are much less, 35 , to be precise as compared to around 210 laywomen and 87 nuns indicating popular base of Buddhism.

Following inscription gives an insight in the prevailing economic life as well as the very good economic sense showed by Vishnudatta, a laywoman while planning and investing the money she donated for the benefit of the Sangha around 1700 years ago. Vishnudatta Shakanika, the daughter of Saka Agnivarman and the wife of Ganapaka (accountant) Rebhila and the mother of Ganapaka (accountant) Vishnuvarman is said to have donated some money for the cause of Dhamma ${ }^{8}$ in cave no 10 at Nasik in 258 A.D. ${ }^{6}$ This endowment was meant to provide medicines for the sick among the community of monks from all directions dwelling on the Monastery on the Trirasmi Mountain. ${ }^{9}$ For the aforesaid endowment more than 3500 Karshapana were invested by her. ${ }^{7}$ (1000 Karshapanas with the guild of Kularikas, 2000 Karshapanas with the guild of Odayantrika, 500 Karshapanas with the guild of (name lost) and some more with the guild of Tilapippaka). ${ }^{9}{ }^{10}$ It is very interesting to know that Vishnudatta

\section{${ }^{4}$ Housewife}

${ }^{5}$ Ibid p 53, n.516

${ }^{6}$ This epigraph belonged to the reign of Abhira king Ishvarasena

${ }^{7}$ Karshapana was a silver coin weighing about thirty four grains. Karshapana mentioned here were probably those of the western kshatrapas, which appear to have circulated in Maharashtra during the time of Abhiras. Karshapana is also referred in the Dhammapada-"Na Kahapana vassena titti kamesu vijjati" 
invested the money in the guilds such as Kularika (potter), Tilapippaka (oilmen) and Odayantrika (workers fabricating hydraulic machines). The interest accumulated over this money was to be diverted for the benefit of the Sangha. ${ }^{11}$

The inscription of Lavanika at Kanheri ${ }^{8}$ in the cave no. 75 belongs to early 3rd century A.D. This interesting inscription records two grants given by Lavanika at two places, the Kanheri caves and the Ambalika vihara near the ancient port town of Kalyan. ${ }^{9}$ Lavanika was the wife of an upasaka Sethi Achala from Kalyan. She donated cave, cistern, and a tank for bath (Lena, panipodhi and nanapondha) for the welfare of her family. The second part of the donation records her endowment of three hundred Karshapanas for the monks at the Ambalika vihara. This grant was to be utilized for providing Chivaraka ${ }^{10}$ for the monks residing there. ${ }^{11}$ The location of this vihara has been explicitly stated in the inscription as 'near Kalyan'. However, the exact site could not be ascertained. Obviously as Kanheri was a famous place, Lavanika chose to engrave her donation at Ambalika vihara, so that more devotees could come to know of it. There is a mention of another monastery at Kalyan in an inscription in cave no.32 at Kanheri. This Brahmi inscription belongs to 2nd century CE. A merchant Dharma, the Kaliyanaka (a resident of Kalyan and son of Sivamitra) along with Budhaka and his entire family gifted a house with two apartments (vibhaga) and a dining hall in the vihara at Kalyan in an area called Gandharikabhami. ${ }^{12,12}$ Due to the brisk trading activity in the early centuries many west Asian and Greeko-Roman trading communities had settled in Western India. Inscriptions suggest that many women of foreign descent had adopted the Dhamma as the way of life.

Unlike Kanheri where a large number of donors hail from the city of Kalyana, at Karle the majority of donors were residents of Dhenukakta. Many of whom were Yavana ${ }^{13}$ who were followers of Buddhism. The grand Chaitya at $\mathrm{Karle}^{14}$ records the donation of Mahamata, the wife of (name lost) from Dhenukakta has been recorded on the tenth pillar in the left row. ${ }^{13}$ So there is a possibility to assume that Mahamata hailed from a Greek descent like other Greek male donors.

Inscriptions record the existence of nuns. Buddhist ascetics as per law could not possess any property but they must have obtained the money by begging required for making the rails and pillars of the cave temples. This was no doubt permissible as the purpose was pious one. ${ }^{14}$ As a result a large number of nuns have recorded their donations at various sacred places. Here the difference between Jain

${ }^{8}$ The Kanheri Caves are a group of rock-cut monuments, located north of Borivali on the western outskirts of Mumbai. These caves date from 1st century BCE to 9 th century AD. In total in the basalt there have been carved 109 caves excavated.

${ }^{9}$ Kalyan lies $53 \mathrm{~km}$ north-east of Mumbai.

${ }^{10}$ Robes

${ }^{11}$ Ghokhale Shobhana, Kanheri Inscriptions pp. 98-101. The existence of the monasteries along the ancient trade route was not merely a co incidence.

${ }^{12}$ According to Shobhana Gokhale, Gandharikabhami was a residential quarter of the Greeks in the ancient city of Kalyan. Even today there is a small river called Gandhari near Kalyan. It is a tributary of River Kalu. The surrounding area is also known as Gandhari.

${ }^{13}$ There is no unanimity about the origin of the Yavanas. Their places of origin are claimed from Ionia to West Asia

${ }^{14}$ This Chaitya belongs to first century B.C. and is the finest type of Hinayana caves. The Chaitya contains a huge Stupa and thirty seven richly decorated pillars. An inscription in the Chaitya states that this is the best cave in the entire Jambudvipa and was completed by the moneylender Bhutapala of Vaijayanti. These caves are $114 \mathrm{kms}$ away from Mumbai nuns and their Buddhist counterparts can be brought out. Inscriptions reveal that though the Jain nuns influenced a large number of laity to donate for the religious cause that was explicitly mentioned in the donations; they themselves hardly figure as prime donors. However, the Buddhist nuns like nun (Pavaitika) Ponakisana, ${ }^{15,15}$ Bhikhuni Damila ${ }^{16}$ themselves have donated at various places.

There are many references to courtesans who embraced Dhamma in the Buddhist literature. The Therigatha refers to Vimala and Sarama who were sisters acting as courtesans. Amrapali was the famous ganika who resided in Vaisali, the capital of Vriji republic. This tradition continued for centuries down the line. An Inscription from Sannati ${ }^{17}$ dated second century $\mathrm{AD}$, refers to a natika (dancer) named Govidasi. ${ }^{16}$ She constructed an enclosure or Prakara. Another inscription from Sannati belonging to the same period refers to another dancer named Aryadasi ${ }^{18}$. She was the daughter of Nadiya Guda and Nati Valuki. She constructed a Mukhudika or lofty entrance hall.

\section{Conclusion}

The history of Buddhism is incomplete without understanding the contributions of these capable and confident female followers of Dhamma. Although these women hailed from different periods and geographical areas, and from different social and financial strata, they had one thing deep rooted in common: a passionate involvement with the teachings of the Buddha.

\section{Acknowledgments}

None.

\section{Conflict of interest}

Author declares there is no conflict of interest in publishing the article.

\section{References}

1. http://wcd.nic.in/stat.pdf

2. Karmarkar R. Annals of Bhandarkar Oriental Research Institute. Digital Library of India. 1953;34:30.

3. Hultzsch E, Konow S, Mirashi VV. Corpus Inscriptionum Indicarum. Epigraphical Publications. 1991,1997;1,2,4:159.

4. Dasia ZA. Epigraphia Indica. Manager of Publications. 1909; 10:27(n.177).

5. Kane, Vaman P. History of Dharma Shastra. Bhandarkar Oriental Research Institute. 1941;2(1): 272.

6. Dasia ZA. Epigraphia Indica. Manager of Publications. 1909; 10:33(n.245).

7. Dasia ZA. Epigraphia Indica. Manager of Publications. 1909;10:31(n.226)

8. Dasia ZA. Epigraphia Indica. Manager of Publications. 1909;10:127,114.

9. Mirashi, Vishnu V. Corpus Inscriptionum Indicarum. Government Epigraphist for India. 1955;4:114.

${ }^{15}$ Ponakiasana has another title, theri (elder nun) indicating her superior status in the Order.

${ }^{16}$ Ibid pp. 106 (n. 1013) Both these nuns have donated at Kanheri.

${ }^{17}$ Sannati is a small village, located on the banks of the river Bhima in Chitapur taluk of Gulbarga District of Northern Karnataka.

${ }^{18}$ Ibid 
10.Dasia ZA. Epigraphia Indica. Manager of Publications. 1909; 10:127(1137).

11. Dasia ZA. Epigraphia Indica. Manager of Publications. 1909;10:127.

12.Dasia ZA. Epigraphia Indica. Manager of Publications. 1909;10:104(n.998).

13. Dasia ZA. Epigraphia Indica. Manager of Publications. 1902;7:52,83-84.
14. Dasia ZA. Epigraphia Indica. Manager of Publications. 1909;10:369.

15. Dasia ZA. Epigraphia Indica. Manager of Publications. 1909;10:105(n.1006).

16. Sarma IK, Rao JV. Early Brahmi Inscriptions from Sannati. Harman Publishing House, India; 1993. p.136. 